balance of birth in a context of Cicero's death (75); the ironic personification of the disease troupe besetting the old man and making them look livelier than their poor moribund host (I33; vv. 2I8-19) - most pages will have at least a couple of these insightful flashes of local colour. A particular strong suit is the intertextual sediment with which M. loads the poem, drawing from a wide repertory of authors: Seneca, with Thyestes' golden cup underlying v. 27 (29); Lucan, e.g. regarding Alexander's non sufficit orbis at v. I68 (IOI; cf. Lucan 5.356 and IO.456); or even Ovidian elegy, with the instructions to the girls to suppress their perpetual laughter (Ars Am. 3.285), enjoying Juvenal's didactic flip to build a world in which perpetual laughter is the only feasible reaction (3 I, on v. 33). M.'s wide-ranging scholarship on Latin literature certainly pays dividends for regular, energising and responsible comparisons.

The rich and sophisticated reading should be the take-home of the book. But there are also a host of additives which leave a sour taste. The first is M.'s bizarre tendency to argue with Juvenal as if we readers were in danger of taking this overblown and hyper-tensed satirist as a dispenser of truths. Several times M. intervenes to 'correct' the flawed Juvenalian argumentation, but his well-meaning liberal fussing turns backfire betrayal of his own ideological commitments. He criticises panem et circenses (v. 8I) for giving a reductive view of the Roman plebs: 'this cannot have held true of all the Roman commons, as at least some of them would have felt strong desire for food other than bread, and for other types of shows (gladiatorial etc.), and for other things as well (wine, sex, etc.)' (52). Heaven forbid thinking that 'commons' capable of desiring something beyond their bodily needs. Likewise, some strange defence of Juvenal's oversexed women (on v. 323): 'it is simply not true that all degenerate females are totally dominated by sexual desire or that their character is completely unaffected by other elements (such as spite, envy, greed and the will to survive)' (I 83). We are lucky to have M. to point out the untruth and expand women's range of motivations to spite and greed as well as sexual desire (!). Less disturbing and more frustrating are the strained chapter sign-offs, where M. devotes a single short paragraph to a touch of modern-ish 'reception', e.g. Ben Jonson (63) or Dryden (I60). These add sweet zilch, and should have been scrapped.

Overall, this is a sound first entry point to a classic poem, and will serve its readership well for a good while. The main thrust of the book plays to M.'s strengths: close reading, irony explaining, allusion unpacking. The attempts to strike out beyond traditional Latinist territory go south but as Sat. Io asseverates, there's no point wishing for more when our basic needs are met.

University of St Andrews

Tom Geue

tag8@st-andrews.ac.uk

doi:I0.I0I7/S007543582000089I

\title{
CHRISTOPHER NAPPA, MAKING MEN RIDICULOUS. JUVENAL AND THE ANXIETIES OF THE INDIVIDUAL. Ann Arbor: University of Michigan Press, 20I 8. Pp. xii + 224. ISBN 9780472I30665. £6I.95/US\$75.00.
}

As motto to his analysis, Christopher Nappa has chosen the epigrammatic sentence from Umbricius' complaint, which also explains the title of his book: 'nil habet infelix paupertas durius in se / quam quod ridiculos homines facit' (3.152-3). His translation of homines as 'men' is programmatic, and shows the direction of his study, which centres around elite Roman males, examining what defines elite identity and what threatens it. Reflecting upon this question methodically, N. himself concedes that focusing on elite anxieties about their identity could be a 'side-effect rather than a goal of the poems' (8). In contrast with the recent tendency to elaborate on the invisibility (J. Uden, The Invisible Satirist (2015)) or anonymity of the satirist in the sense of a conscious self-concealment (T. Geue, Juvenal and the Poetics of Anonymity (20I7)), N. returns to spotlighting the Juvenalian satirist.

Before explaining the concepts of class, gender and wealth basic to his interpretation in his introduction $(\mathrm{I}-22), \mathrm{N}$. presents issues connected with the persona theory. In ch. I (23-60) he offers a close reading of the programmatic first Satire. In his analysis he constructs a tension between the figure of the satirist as conceived by Juvenal and his actual realisation: while the poet opposes poetic clichés and instead claims to attack current vices, he in fact falls prey, time and again, to exactly those conventional and mythological patterns of thinking during the course of the first poem. According to N., the satirist also fails as a new Lucilius regarding his frankness of 
speech (I.I9-20), because in the finale of Satire I he confesses to limiting himself to criticising only the dead. As a result, the satirist fails also as a man insofar as he has been restricted in his autonomous freedom. To N., autonomy is 'the fundamental building block of Roman manhood' (22).

In the following chapters, $N$. analyses various passages dealing with the anxieties of the male elite. Ch. 2 considers rebellious bodies and anxieties over the lack of autonomy (6I-92). N. looks at the body as an emblem for the individual human being, therefore Juvenal's bodies show 'who one is in Rome's hierarchies' (62). In 'The Obliterated Body' (70-7), N. interprets physical vulnerability as a metaphor for impending social death. Instructive is his statement regarding surrogate bodies $(82-5)$, such as the mutilated statues in Satire 8, to which Juvenal applies similar body imagery.

In ch. 3 (93-I 26), N. discusses a variety of men who have debased themselves willingly. They are case studies in class betrayal, defined by $\mathrm{N}$. as 'engaging in behavior inappropriate for one's social class' (I2I). Examples include Creticus appearing in court in a diaphanous robe (Sat. 2), Lateranus, the mulio consul (8.I48), aristocrats on stage (Sat. 8) and Gracchus, the Salian bride, performing as a gladiator in the arena (Sat. 2 and 8 ). N. correctly points out the potential effect on the audience (cf. I09), but why does he ignore the negative examples of women, such as the meretrix Augusta (6.1I8)? Women and men as representatives of the social and political elite are equally targeted by satiric criticism, when religious and state institutions are publicly disgraced by their scandalous behaviour. Yet for N.'s Juvenal, 'all relevant individuals are male' (2); see also a parenthesis like 'and, as usual, Juvenal is thinking only of men' (79). In fact, Juvenal's satirist criticises any behaviour which deviates from the norms determined by gender, religion, age, social status or political office.

In chs 4 and 5, masculinity under threat is also the prevailing topic. In ch. 4 (I27-65), N. studies womanly behaviour and various kinds of effeminacy based on passages from Satires 2, Io and, above all, from Satire 6. There Juvenal reveals his male anxieties concerning gender, and thus exposes himself; in the author's own words, 'Juvenal attempts to stage a freak show, and he and Postumus turn out to be the star attractions' (I 30 ). According to N., 'the world of women and their allies [...] constitutes a kind of shadow-land that threatens to displace the civic world of male privilege' (I99). $\mathrm{N}$. reduces women to wives - adulterous, wasteful or unwilling to bear children. It has to be pointed out, though, that it is the abnormal behaviour of a woman of some standing in the first four outrageous cases (not only three, as N. mistakenly believes (28)) which among others provoke in the satirist the urge to write satire (I.22-30): Mevia performs publicly as an Amazon (22-3).

In the final ch. 5 (I67-95), N. focuses on the connection between wealth, its control and masculinity. Interpreting Satire 9, he shows how money can replace deficient manhood when the wealthy, sexually passive patron purchases proof of his paternity from a client, the gigolo Naevolus, who is not only his own lover, but has also fathered children with his wife, so the patron himself can enjoy social and financial privileges.

N.'s discussions of the text are generally philologically sound. However, he might have benefitted from W. Kißel's research report (Lustrum 55 (2OI3)), which provides a detailed overview of the relevant scholarly literature published between I962 and 20II. By and large, N.'s stimulating book - which offers numerous illustrative modern analogies, especially American - sharpens our understanding of elite male anxieties.

University of Münster

schmitz.christine@uni-muenster.de

Christine SCHMitz

doi:I0.I0I7/S0075435820000222. This is an Open Access article, distributed under the terms of the Creative Commons Attribution licence (http://creativecommons.org/licenses/by/4.0/), which permits unrestricted re-use, distribution, and reproduction in any medium, provided the original work is properly cited.

CARSTEN H. LANGE and JESPER M. MADSEN (EDS), CASSIUS DIO: GREEK INTELLECTUAL AND ROMAN POLITICIAN (Historiography of Rome and Its Empire I). Leiden: Brill, 20I6. Pp. xii + 364. ISBN 9789004324I69. €I 48.00/\$I62.00.

Reviewing Lange and Madsen's collection of investigations into Cassius Dio's Roman History already has the feel of a retrospective, even though only three years have passed since its publication. The editors themselves indicate why in their introduction. They begin not with a 